\title{
Antidiabetic Activity of Fish Oil from Sardinella longiceps Against Wound Pathogen in Diabetic Patients ${ }^{\dagger}$
}

Joe Vinushia A. ${ }^{1, *}$

1 Department of Microbiology, Kamaraj College, Thoothukudi-628002, Tamil Nadu

* Correspondence: joeveronica05061998@gmail.com;

$\dagger$ Presented at International e-Conference on Bioengineering for Health and Environment (ICBHE 2020)

Received: 5.07.2020; Revised: 10.07.2020; Accepted: 12.07.2020; Published: 15.07.2020

\begin{abstract}
Diabetes mellitus is a serious problem worldwide. It arises due to the failure of the pancreas to secrete insulin, which is mandatory to maintain a normal blood sugar level. Deficient insulin action cause diabetes. In this study, oil was extracted from Sardinella longiceps by appropriate techniques. The antidiabetic activity was examined by an alloxan-induced method. It resulted in decreased blood sugar levels.
\end{abstract}

Keywords: Diabetes mellitus; fish oil; Antidiabetic activity.

(C) 2020 by the authors. This article is an open-access article distributed under the terms and conditions of the Creative Commons Attribution (CC BY) license (https://creativecommons.org/licenses/by/4.0/).

\section{Funding}

This research received no external funding.

\section{Acknowledgments}

This research has no acknowledgment.

\section{Conflicts of Interest}

The authors declare no conflict of interest. 